Borivoje B. Prokopovic ${ }^{1}$

Miloje A. Jelić

Gojko Veličković3

Business school of Nis
ORIGINAL SCIENTIFIC ARTICLE

DOI:10.5937/ekonomika1703025P

Received: May, 31, 2017

Accepted: Jun, 30, 2017

\title{
IMPLICATION OF BETTER ECONOMIC CONDITIONS
}

\begin{abstract}
There is no economic growth and development where there is no clear economic policy and development strategy, that is where there are no defined priorities, nor mechanisms for a strong and systematic support to the domestic economy. The author of this study advises economic policy makers to forget the mantras of neoliberal policies that previous governments used as an excuse not to take anything and to resolutely turn their own economic development and building a strong industrial sector. That would be a shortcut to rapid economic development and bridging the decades of stalemate and stagnation. Serbia does not lack resourcefulness, but quality state apparatus, as well as guidance and assistance in the way that countries that have successfully developed did.

The greatest sin of our economic policy in the last quarter of a century is a tragic neglect of industry, especially manufacturing, or as a result of all this, and the emergence of a deep ravine between production and consumption, and totally neglecting technological development. Therefore, we are firm in the belief that, in the case of seriously disturbed the economic structure of production at the expense of our future development must rely on priorities, among which would be the development of the manufacturing sector of the economy, and within it of agriculture and food industry, where our chances are objective and greatest.
\end{abstract}

Key words: Profit making, development, partocracy, market...

JEL classification: 010, 012, 040, E13

\section{НАГОВЕШТАЈ БОЉИХ УСЛОВА ПРИВРЕБИВАЫА}

\section{Апстракт}

Нема привредног раста и развоја тамо где нема јасне економске политике и развојне стратегије, односно где не постоје ни дефинисани приоритети нити механизми за снажну и систематску подршку домаћој привреди. Аутор овог рада саветује креаторима економске политике да забораве мантре неолибералне политике, које су претходним владама служиле као алиби да

\footnotetext{
${ }^{1}$ boraprokopovic@gmail.com

${ }^{2}$ jelic.m@mts.rs

${ }^{3}$ gojko.v@mts.rs
} 
ништа не предузимају и да се одлучно окрену сопственом економском развоју и изградњи јаког индустријског сектора. То би била и пречица за убрзани економски развој и премошћавање вишедеценијског застоја и стагнације. Србији не недостаје предузимљивост, већ квалитетан државни апарат, али и усмеравање и помоћ на начин како су то радиле земље које су се успешно развиле.

Највећи грех наше економске политике у протеклих четврт века је трагично запостављање индустрије, посебно прерађивачке али, као последицу свега тога, и појаву дубоке провалије између производње и потрошње, те потпуно запостављање технолошког развоја. Зато смо чврсти у уверењу да се, у случају озбиљно поремећене привредне структуре на штету производње, наш даљи развој мора ослањати на приоритете, међу којима би био развој производног дела привреде, а у оквиру њега пољопривреде и прехрамбене индустрије, где су нам шансе објективно и највеће.

Кључне речи: Привређивање, развој, партократија, тржиште...

\section{Introduction}

The time in which we live is characterized by extraordinary dynamics of total change and very rapid transformation of all aspects of human existence. In this context, the economic changes deserve special attention, since changes in this sphere, undoubtedly, have the dominant influence and affect all other changes. Of course, in this paper we will discuss only some issues of socio-economic life and the tendencies of movement and development without pretension to have a complete and full analysis.

On the world scale, the process of transition and privatization is being put in practice, as a world trend, and as a response to globalization, which promotes market economy on a planetary scale. Today's system of international economic relations is under sovereign rule of most developed countries, which have imposed their own criteria of economic behavior, believing that they are objectively the most acceptable from the standpoint of economic efficiency.

Economic systems and their economic actors today are difficult to adapt to the speed at which the world is changing, and often do not have with whom to share the anxiety that puts pressure on them. It is known that in the US it is most frequently debated on consolidation rather than on measures of growth and development, which is why it is rational to ask a question on the presence of Serbian strategy and whether the experiences of other research in this area (so called "Economic miracle", the Asian "tigers and dragons" and the like.). ${ }^{1}$ And we cannot understand that the problem is a dramatic speed at which the world is changing, and that the forms of economic relations that were in force twenty years ago are almost completely overcome. We believe that the greatest sin of our economic policy in the last quarter of a century is a tragic neglecting of industry. ${ }^{2}$ Also the manner of their manifestation has changed. That is why a number of problems occur along with disorders that were previously unknown. Depression and instability, as well as any other disruption in economic activity, have a very complex assembly. It can 
be associated with severe early stage in development, sometimes in conjunction with changes in the environment, including the sensitivity of the global economic system. Therefore, the discovery of the cause is always difficult, but fortunately, the aid can (and should) be looked for at several sides.

Dogmatic attitude towards current economic conditions and the organization disable an efficient economy slow down development.

Serbia is faced with the processes of decisive battle for new and acceptable conditions for our model of the economy, but also against corruption, which seriously affected part of the bureaucracy. This is a kind of indication that we are getting closer to confrontation with the exigencies of time of which we are contemporaries. ${ }^{3}$ On the other hand, our social moment is becoming more dramatic, and one of the key reasons is still insufficient readiness and determination to significantly alter economic conditions and organization of the economy. In this we are standing still. All the changes in economic conditions and the organization of the economy given in the proposals from various scientific meetings (Kopaonik forum, etc.) and in other professional documents, make these very important questions. Changes which are appealed at in scientific meetings, in terms of strengthening the subjectivity of small and medium-sized enterprises, are still more declarative in nature (in terms of subsidies, reduction of various taxes, etc.), and we know that this is the most significant change that should be supported in order for these companies to become true subject of market economy operations. This plan of economic conditions and changes in the organization of the economy, and to underline, is still lacking serious reform efforts. Without an open confrontation with the fact that with such a sufficiently reformed economy, weak accumulation - where investment decisions are left at the level of government - press local interests and power, which has an absolute monopoly on the job, we cannot emerge from this still dramatic situation. If this situation remains unchanged - as is seen by the representatives of the government still unreformed economy - structurally unadjusted and without prioritization, where both power and powerlessness draw from a multitude of territorial political centers, it will greatly diminish the importance and value of the solutions to which there are proposals to strengthen small and medium-sized enterprises in the line of further strengthening of the market.

\section{Economy grows for some time}

The fact is that the economy, according to some basic indicators, has lately been growing, but this growth is not yet at the required level. However, we should be satisfied with the results achieved in 2016, as they provide the basis for achieving objectives in 2017.

Table 1: The fiscal strategy for 2016. with projections for 2017 and 2018.

\begin{tabular}{clcccc} 
No. & Elements & \multicolumn{4}{c}{ Realization in \% } \\
& & 2015. & 2016. & 2017. & 2018. \\
1. & Inflation & 1,5 & 2,8 & 3,9 & 3,9 \\
2. & Investment & 8,2 & 6,6 & 6,2 & 5,5 \\
3. & Export & 7,8 & 7,7 & 7,0 & 6,7 \\
4. & Import & 6,0 & 5,8 & 4,4 & 4,3
\end{tabular}

Source: Budgets inquiry of the author 
It should be noted that the European Commission remained in Serbia's economic growth projection for 2017 and 2018 at 3 and 3.3 percent, foreseeing an increased drop in unemployment (from 16.1 to 14.3 in this, and to 12.6 in 2018). According to this projection private consumption will also rise by 2.1 this year, and 3 percent in 2018, the acceleration compared to 1.2 percent in 2016. Domestic consumption will grow by 2.5 percent this year and 2.4 in 2018, compared to growth of 2.7 percent in 2016. N Export of goods / services this year will grow by 7 , and in 20186.7 percent, compared to growth in exports of 10.9 percent from last year, while imports will rise by six, or 6.3 percent, compared to growth of 7.7 percent in 2016.

Serbia's public debt last year was reduced for the first time after many years of constant growth. However, one should expect that the pace of fiscal consolidation will somewhat slow down this year, but it will be sufficient to continue the further decrease of the public debt.

In discussions about the causes of the situation in our economy, there is expressed dislike of criticism that have led to a serious relationship with the current government solutions in the field of economy. Such repulsion has also been expressed by those of the opposition, because it still is not anything serious going on in terms of the economy and the organization of the economy. According to the presented data like this, we cannot expect any serious changes even when it comes to further efforts of entrepreneurs. We believe that without getting into serious structural changes in the economic conditions and organization, the economy cannot be released from the shackles of internal pressures, exaggerated party arbitration, which all together represent one of the major causes of our economic reality, or rather of our still unfavorable economic conditions. It is not about some illusory hopes that with more radical regime change business and organization, easily out of the current situation, but it is a fact that will create a serious structural intervention, a necessary precondition for a faster exit from this business environment. Bad proposals in the way of further and more serious reform underestimate the importance of reforms themselves to get out of the situation that, unfortunately, it can be worse. ${ }^{4}$

There multilayered causes of such state of our economy. Now before these proposals this problem is tried to be alleviated by improving the economic conditions for small businesses, investment and foreign capital, creating opportunities for higher yield agriculture and introducing new incentive system. These are, quite clearly, significant changes. However, the primary cause of the issue of unresolved problem of large systems is from the public sector. It has become a first-class socio-economic issue, because also a lot of public entities by local governments, whose common goals and interests are marginalized, the ebbing affects and weakens the effectiveness of the reproductive capacity of the overall economy. And where there are marginalized common interests and objectives, it must be reflected in the formal question of the budget of the whole country. In addition, the law constituted a multitude of subjects to introduce a variety of duties, which in the past caused a disproportionate development of the non-economy. 


\section{A big illusion}

Similarly, the "ideological sin" today is to say (when we are still pressing hard and high unemployment rate) that it is necessary to invest funds into the economy of the country, to encourage the development and acceleration of solving unemployment. If so doing, it should not be considered as a deviation from the principle of belief, because we fear that we are excessive state intervention in economic investment can go back leads nowhere. It would be much more negative disproportionate investment in non-economic activities (regardless to the real needs of the area), which in relation to the bad economic situation meant the right to extravagance. Now that unemployment is falling, there is less need for state intervention in economic investments

Increasingly, it is said that more should be done to strengthen the capital market, or type of securities. However, there is an illusion that the introduction of securities, especially some of them, will show vitality and a result if it is not relied on and there is a space in the dynamics of the rest of the economy.

Today, some point out that with the economic growth, that is the current state of our economy, it can only go with the actual level of market goods, but that it should be further developed and strengthened labor and capital markets. We agree and ask: Do countries, with highly industrialized market economies, their vitality and ability in politics of earning more, draw power from the cohesion and concentration of resources in companies and systems in the market of goods.

It is unsustainable contradiction that, on the one hand, underestimates the importance of cohesive strength and power companies and systems, primarily to increased production, while also attaches so much importance of the capital market (though not disputing the need and this important instrument). Because there can be no vitality of capital markets in an economy that is structurally disorganized. With a change to this state the only gain would bi in a corporate sense globally.

Likewise, the fact is that official institutions are in the real war against the gray economy, which also shows an increasing tendency to strengthen. You may, as long as you want, attack this action, but it is a major economic sin to say that we do not need Tax Administration, as it is (this does not mean that it cannot be reorganized), where there is a huge professional potential hired (with a strong illusion that it is able to eradicate this dangerous obstacle of enterpreneurial motivation, initiative and resourcefulness legal part of the economy), still with the old organization of work, with great illusion that only with its inherent motives it would be led automatically to a successful prevention in their activities, which is to a large erosion of personality of the individual and the like. And that subjectivity has risen in the Directorate and became in many ways present with its arbitration role, because it was broken fasteners.

We have to learn that under the large organizations and large systems we think of public sector integrated human resources, rather than a mechanical conglomerate created. In the public debate on the Law on public companies, professional forces of our society gave their valuable contribution (if the current shift state will disappear personality of the individual) will be organized professional power holders of a successful fight against the gray economy.

Political particularism imposed a lot of conflicting methods of mixing in the economy, by something opportunistic, and on other bureaucratic. So that when a scandal 
erupts, it often meets the challengers, regardless of whether it touches livelihood. If this practice took broad conditions it is clear that we are pushing to ruin. Undeveloped and disturbed political relations explanation for many measures, while declaring the disturbed political relations (which, by the way, also touches legal institutions) introduces the principle culprits of all, this is a killer for power drawn to progress.

\section{The key problem of Serbia is that public companies are slowly becoming independent}

On the issue of overriding importance of so-called partocratic monopoly, appearts the interpretation that there is a class interest politocracy to ensure its absolute monopoly in the economy, politics (the state-party complex) and ideology (monopoly on ideological rationalization and ideological monism). The prospect of getting out of this situation is to further strengthen the democratic forces. The fact is that today we are still very pronounced state party power in the enterprise, and that we need to correct this situation. It is not understandable, it is too simplifying things, to interpret the state of heritage and interests that it held. Excessive partocracy at the top of the country requires a broad arbitration entire economic complex. The essential question is the dogmatic attitude towards current economic conditions and the organization of the economy, which is not fast enough changing the relationship of the economy and politics, that is, the faster the economy cannot become independent in relation to politics. Especially this applies to state-owned enterprises.

It happens so that the Law on Public Enterprises, which was adopted in March last year, according to which a director cannot be a member of any political party, is not observed. Some of the current directors of enterprises, especially large, largely confirm that. ${ }^{5}$ There are still no terminated connections between ownership and management, and it is supposed to be of key importance for alternatively management of public enterprises. The government should continue to remain the majority owner of public enterprises, but not to manage them. Since, even in the case of freezing the status of the party managers of public enterprises, this principle will not be met, given that the time relationship between the party and the director does not break. For, in that it has set a party, instead of working on the company, must work in its interest. It is known that the reform of public enterprises is not easy and simple, but it's the last ballast of public finances. Because when the party in control of public companies, then they sort of testing ground for partisan employment, through them there is social policy, funding from various projects and the like. It is no coincidence that the IMF will in the last third of the program with Serbia, which was deposited by the end of February 2018, the emphasis placed on these enterprises.

Under the new conditions, in the reformed public enterprises director should have full freedom in managing the company, and that only measure of success are the business results. A state, as the owner of a public company, should, in this connection, set targets against directors and to control how they are achieved.

If you stick to these economic conditions, in such an organized economy, it is difficult to talk about breaking the constraints of the market economy development and the weakening of the political power in the economy. Full momentum of development 
of the market economy is the one essential step forward to preserve the acquired values of democratic change, and the development of the economy strengthen market function.

Dogmatic attitude towards current economic conditions and the organization of an efficient economy and hampers effective in slowing down the development of society. Behind the resistance changes quicker lies the fear that this would lead to dominance of others, fear of partocratic leakage and breeding of big illusion that the existing relations to compensate entrepreneurial motivation, resourcefulness and initiative. This situation in our business dealings and stubbornness partocracy in efforts for the survival of the existing one, creating a rich supply of tendencies that affect some elements of the past. And they are increasingly open to hear claims that without political pluralism there is no market or economic democracy. It is clear, therefore, that the question of market economy, in the sense of imposing an economic objective and as a means to force the parties to withdraw from the economy and its arbitration situation finally has to set properly. A tapping only in showing that the power in the middle of irresponsibility and the only control factor that can bring some kind of responsibility and their political pluralism.

\section{Affirmation of expertism in economy is a necessity}

The reform implemented in Serbia is a necessary prerequisite for certain serious structural interventions in economic conditions and organization that we have. But there are still blockages in concrete solutions and market principles themselves, but for our situation the only alternative may be persistence in market principles, i.e. the deviation from partocratic structure. That is why we think it has emerged a moment to the question of the extent to which previous changes we managed to leave the decision that blocks the realization of the very market principles and affirmation of free and European-oriented economy?

Important issues and government decisions must be considered by the world's search for the best solutions to the current problem arose, of course, with the involvement of the best. Serbia now has a lot of strong community of intellectuals, but it is quite unevenly developed and insufficiently used by those in need. This is especially evident in the field of social sciences, which require better communication and more desirable intellectuals of all profiles with the economy. This would bring economy into a position that makes better use of intellectual potential, and this would be easier to come out of its frame. Of course I am of the opinion that the intellectual community should be more directed towards finding concrete solutions to economic problems, because it is in their mutual interest. Some segments of our intellectual community are good, and to those whose previous (socialist) system was unable to inflict great damage: Mathematicians are mathematicians in one and in the other system, and they could not have much to suffer. They do their job the same way. But economists are in a different situation, we are in a great controversy among us, we can find two blocks, two camps: one insists on state interventionism and the other is against it and points out that where the state interferes there is corruption, there are abuses there are errors independent of corruption and abuse, because when the state interferes big moves are pulled and such are the risks of these huge mistakes 
Serbia today lacks organization and reduction of administration, bureaucracy and unnecessary amount of regulations, paperwork, and taxes (especially on wages). Today, this view has become quite normal, given that the new EU-conditions the government will be constrained by national borders, it will present important new challenge. And how, in practice, observed clearly in the trade, which is nothing new. It is generally known that countries and companies doing business with each other for centuries, and trade is of great importance for human health, prosperity and well-being of society. Today countries are in a position to benefit from the exchange of economic development and productivity, as specialize in the production of goods / services for which they are best for imports of the same, which is the most efficient products elsewhere.

All this should be more precise and decisive when put in measures built into the economic policy of the current government, ${ }^{6}$ so that the affirmation of different forms of ownership in the US gain and experience the true meaning. Our impression is that the starting point of capitalism in Serbia set too narrow and one-sided, so you get too attaches importance to private property. Of course, this should not be perceived as if the time calls into question the capitalist understanding of the importance of private property, but there are various other types of property, such as: cooperative, joint stock, corporate ... If at the beginning of the generalization of private property came as the result of the avoidance of politicians to create consensus on the transformation of the existing property at the time of the fall of the former regime and the beginning of capitalism, we are already far from this time and it is necessary, according to the problem, refer to alternatively.

\section{Concluding remarks}

Contemporary Serbia is faced with the processes of more decisive battle for new and acceptable conditions for our model of the economy. It lacks organization and reduction of administration, bureaucracy and unnecessary amount of regulations, paperwork, and taxes.

Without going into more serious structural change, the economic conditions and organization, its economy cannot be released from the shackles of internal pressures and exaggerated party arbitration. This is one of the major causes of our economic reality, or rather of our still unfavorable economic conditions. It is not about some illusory hope that we will, with the radical changes in the regime of economy and organization, easily out of the current situation, but it is a fact that it will create a serious structural intervention, a necessary precondition for a faster exit from this business environment.

The primary cause of the unresolved problems issue is of large systems in the public sector. It has become a first-class socio-economic issue, because of also a lot of public entities by local governments, which are the common goals and interests of the marginalized, the ebbing affects and weakens the effectiveness of the reproductive capacity of the overall economy.

Serbia needs full swing in the development of market economy, as a necessary step forward in order to preserve the value of acquired democratic changes and development of the economy strengthen market function. 


\section{Bibliography}

B, Masic., et al. (2010), Management: Principles, Concepts and Procesesi, University Singidunum, Beograd.

B, Krstic., \& E, Kagrovic., Business process outsouring as a tool, For improving enterprise efficiency, Ekonomika, Nis, no 3/15.

B,B, Prokopović., Time for change in cinsumer models, Ekonomika, Nis, no. 2/14.

Borivoje. B. Prokopovic, Bratislav. B. Prokopovic \& Zivojin. B. Prokopovic., Question above all questions for Serbia in 2016 is The reform of The StateOwned enterprises, Ekonomika, Nis, no 3/16.

D, Dujava., J, Rab., How different monetary rules lead to different performances during the case of the Western Balkan contries, Ekonomika, Nis, no. 4/15.

J. Radovuć-Stojanović., The cyclical sharcter of economic policy in Serbia 20012012. Economic annals, 202/14, Belgrade.

Marina, Djordjevic. \& Dusan., Petrovic., Crisis impact on Changes in implementing monetary of Central banks, Ekonomika, Nis, no 3/16.

Marija, Vukovic. \& Milisav, Andjelic., Specific funding of Fiscal deficit in Serbia, Ekonomika, Nis, no 2/16.

$\mathrm{N}$, Zakic, (2009), Innovation and business process management, Foundation Andrejevic, Belgrade.

Radmila, Micic., Lesdership role in certain phases of Knowledge Management processes, Ekonomika, Nis, no 4/15.

Romer, D., (2012), Advanced Macroeconomics, McGeaw-Hill, New York.

Rosen, H.S., Gayer, T., (2010), Public Finance, McGraw, New York.

Rubin, J., (2008), Public Budgeting: Policy, Process and Politics (ASPS Classies), Hardcover.

Z, Prokopovic, M, Nikolic., \& K. Prokopovic., (2012), Protection of the ecosistem approach and sustainable development report at the International Conference (sponsored by the Ministry of Education), "Environment and economy adaption to climate change", Belgrade.

Yar, A., Sarawak, M., Arif-Affendi, M., (2013), Privatization and Fiscal Deficit: a Case Study of Pakista, Researsh Journal of Finance and Accounting, 4 (14). pp. 1-10.

The World Bank (data), available at gttp://data,worlbank.org/. (Accessed 10 June 2017)

\section{Endnotes}

1. The economy of the 13 countries in the world has been increasing at an average rate of 7 percent or more in a succession of 25 years. Among them was one from Europe, the Middle East, Africa and Latin America. Some of these countries are rich in raw materials, others are without sufficient resources, some are the giants, while the others are dwarves, and some often have different political systems and historical experiences. 
2. Serbian economy in the eighties with its own knowledge designed and manufactured industrial robots and numerically controlled machine tools and massively exported them around the world, including the US and Germany, which indicates a total disrepair and unused technological possibility.

3. What we need is a rational and cheap country, efficient administration, low taxes, safety for capital and alike. Because of that, further and more energetic improvement of business environment by our side is necessary in all the fields: fighting the grey economy and unfair competition (that do not make $20 \%$ but much more than that and is present even in big companies), because that can for sure push us forward. If the surrounding countries have now a simpler procedure, which is key to attracting investment, why we do not do the same thing?

4. A reduction in the payroll tax was announced, which would have been the right thing and step in assisting entrepreneurs. And how much it is important to our businesses and their competitiveness in the region, the fact that the neighborhood (Romania) income tax 30 percent and 20 percent (Albania and Bulgaria), whereas with us the percentage 67 points. In addition to income taxes in these countries is 10 percent, when all analyze on, it is clear which side is competitive advantage.

5. Examples of directors are obvious proof that this law remained a dead letter. They many years of state water companies operating at a loss, and the state are covered by the taxpayers (the budget): D. Bajatovic, dir. "Srbijagas" M. Grcic A duty completer dir. EPS, Z. Drobnjak, A duty completer dir. "Roads of Serbia and D. Djurovic, dir. "Corridors".

6. At this moment Serbia needs 5 to 7 billion of investment annually to achieve the medium-term level of standards seriously approaching the developed world. This requires that the government and the relevant ministry development policy spun clear whether greater support for exports of raw materials (wheat, corn, sugar, fruits, vegetables ...) or finished products. 